\title{
Numerical simulation of groundwater flow and temperature distribution in Aegean Coast of Turkey
}

\author{
D DÜşüNÜR-DOĞAN* and S ÜNER \\ Department of Geophysical Engineering, Faculty of Mines, Istanbul Technical University, 34469 Maslak, \\ Istanbul, Turkey. \\ *Corresponding author.e-mail: dusunur@itu.edu.tr
}

MS received 21 September 2018; revised 22 January 2019; accepted 3 February 2019; published online 4 June 2019

Geological studies indicate that one of the most important geothermal systems of Turkey is located in the western Anatolia. There are plenty of studies covering the geological, geophysical and modeling aspects on land. In this study, for the first time, we construct coupled numerical models of fluid flow and temperature offshore Gulf of Izmir and Seferihisar-Doğanbey, using constraints from marine seismic data, which reveal pockmarks, mud volcanoes, and fluid vents. The numerical models were designed by taking into account of main tectonic structures such as Izmir Fault, Doğanbey Fault, Tuzla Fault and Seferihisar Horst. It is found that hydrothermal circulation pattern is influenced by the combination of presence of faults, sediment thickness and seafloor bathymetry. The models here give new insights into the future studies on the possible fluid transport mechanisms.

Keywords. Aegean Sea; western Anatolia; Gulf of Izmir; fluid flow; temperature; numerical model.

\section{Introduction}

Most research and modeling of hydrothermal systems have focused on deep-sea hydrothermal vents (e.g., German et al. 1996; Humphris et al. 2002; Singh et al. 2006; Fontaine and Wilcock 2007) and onshore hydrothermal/geothermal systems. Potential importance of hydrothermal system in shallow marine environments is investigated by various researchers (e.g., Sedwick and Stüben 1996; Pichler et al. 1999; Pichler 2005). Discovered shallow-water hydrothermal systems show a transitional behavior between deep-sea hydrothermal vents and terrestrial hot springs. Due to the effects of marine and terrestrial sources involved, this transitional behaviour makes the shallowwater hydrothermal systems complicated. Mixing of water from different sources effects the geochemistry of the hydrothermal system, temperature profile as well as the gas content. This interaction also develops favorable environments for shallow-water habitats. This forms an environment which is unique for not only the geosciences but also biochemistry (Pekçetinöz 2010; Ristova et al. 2017).

The study area, Gulf of İzmir and SeferihisarDoğanbey is located on the western coast of Anatolia, Turkey (figure 1). The converging Eurasian and Arabian plates and effects of $\mathrm{N}-\mathrm{S}$ extension towards the Hellenic arc result in counterclockwise rotation of the Anatolian plate. This southwestward motion is occupied by the dextral North Anatolian Fault and the sinistral East Anatolian Faults since Miocene (McKenzie 1972; Le Pichon and Angelier 1981; Okay et al. 2001). Due to this extensional regime, the region is characterized by 


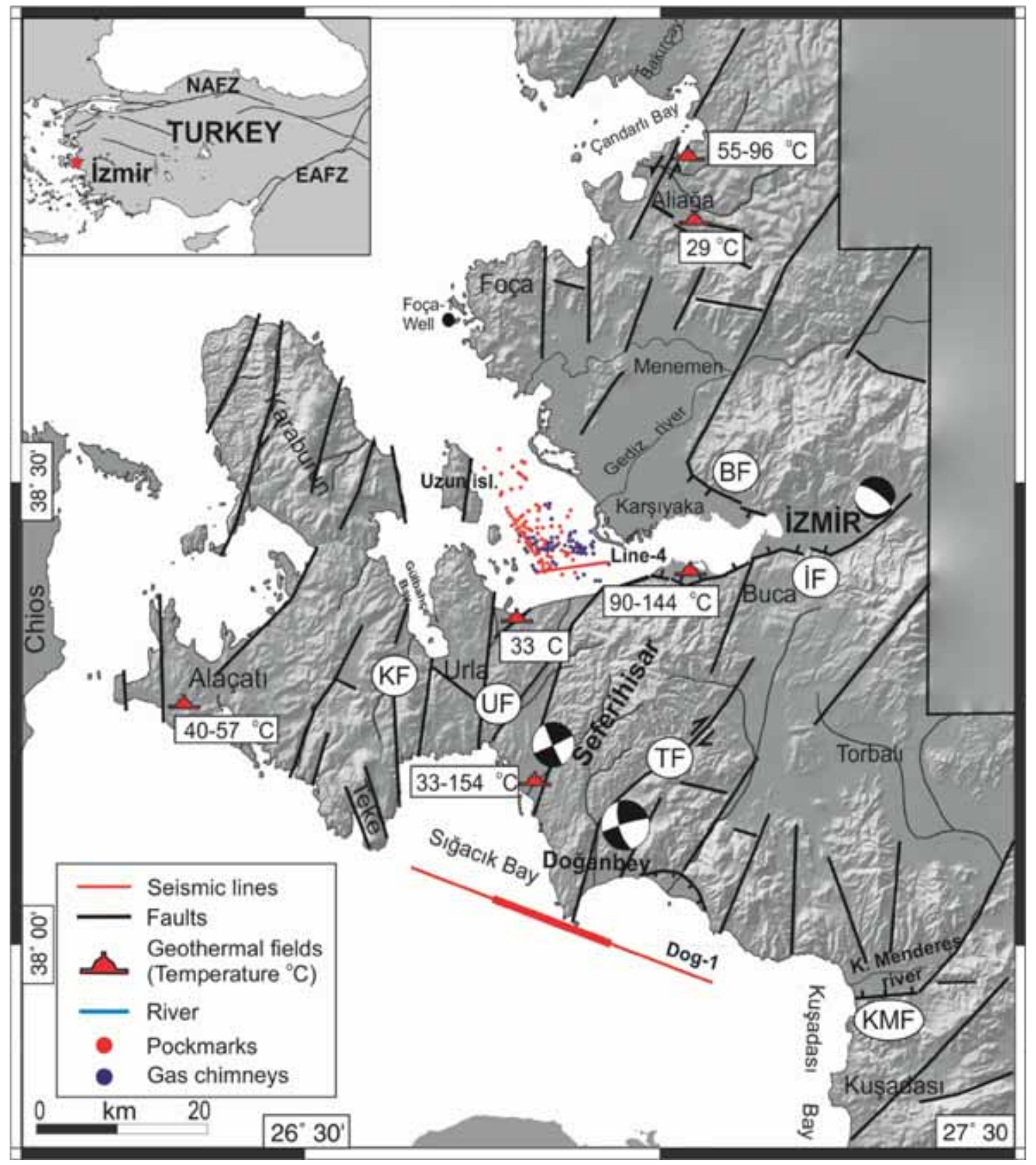

Figure 1. Location map of the study area modified from (Ocakoğlu et al. 2005). Topography map derived from 1:25,000 scale topographic maps of the Turkish General Command of Mapping with $\sim 75 \mathrm{~m}$ precision. Active on land faults; ZBF: Zeytinda $\breve{-}$-Bergama Fault, BF: Bornova Fault, IF: İmir Fault, KF: Karaburun Fault, UF: Urla Fault, TF: Tuzla Fault, KMF: Küçük Menderes Fault. Inset figure shows the study area and the major fault zones (NAFZ: North Anatolian Fault Zone; EAFZ: East Anatolian Fault Zone). Bold red line indicates the seismic section part used in modelling.

thin continental crust, high earthquake activities and high heat flow values up to $150 \mathrm{~mW} / \mathrm{m}^{2}$ (Pfister et al. 1988; İkışık 1995). N-S extensional neotectonic regime has formed $\mathrm{E}-\mathrm{W}$ oriented rift and graben systems such as the Büyük Menderes Graben, the Küçük Menderes Graben and the Gediz Graben. This graben system is highlighted by steep topography associated with active faults (Ylmaz et al. 2000). Extensive geothermal activities in the area and geothermal fields such as Kizildere, Salihli-Kursunlu, Kula-Emir, Aydin-Germencik, are linked to those grabens, active faults and young volcanics (Mutlu and Güleç 1998).

High geothermal potential of the region attracts numerous research groups into the area. A number of studies were performed on land including geology (Bozkurt et al. 1993; Collins and Robertson 
1997; Bozkurt 2001; Bozkurt and Oberhänsli 2001; Güngör and Erdoğan 2001; Okay 2001; Seyitoğlu et al. 2004; Catlos and Çemen 2005; Seyitoğlu and Işik 2009; Candan et al. 2011; Koralay et al. 2012; Ersoy et al. 2012; Gessner et al. 2013) and geophysics (Pfister et al. 1988; İlkışık 1995; Ozel 2000; Sari and Salk 2003; Drahor and Berge 2006; Özürlan et al. 2006; Yagci 2015) concerning to explore geothermal sites, related to the faults and fractures. The four of the main faults located in the area are Izmir, Cumali, Tuzla and Doğanbey Faults, which host many natural hot springs with venting temperatures ranging from 30 to $78^{\circ} \mathrm{C}$ (Tarcan and Gemici 2003) (figure 1). Previous studies on land suggested infiltration of the meteoric water down to at least $2 \mathrm{~km}$ depth (Genç et al. 2001; Serpen 2004; Erdogmus et al. 2006; Aksoy et al. 2008; Magri et al. 2010), heated up by a heat source, and carried up to the surface via those active faults and fractures. Particularly, N-S and $\mathrm{E}-\mathrm{W}$ oriented faults within the southern coast of Gulf of Izmir play an important role in the circulation of hot water (e.g., Filiz and Tarcan 1993; Serpen 2004; Aksoy et al. 2008).

Furthermore, geochemistry and modeling studies were conducted on land (Serpen 2004; Magri et al. 2010, 2012) in order to characterize the hydrogeology, fluid chemistry and reservoir properties. Numerical models of Magri et al. (2010) explored the possible transport mechanism of the Seferihisar-Balçova geothermal system. They showed that temperature pattern results from the interaction of convective flow and meteoric recharge from horst into the faults.

Even though marine seismic and bathymetric studies show presence of fluid vents (Pekçetinöz 2010; Dondurur et al. 2011; Altan and Ocakoğlu 2016), there is no modeling study offshore unlike on land. Pekçetinöz (2010) identified low temperature (maximum $35-40^{\circ} \mathrm{C}$ ) hydrothermal anomalies offshore Gülbahçe Bay. It was also reported existence of the coral habitat and palynomorphs. This cooperation could be suggested presence of hot water outlets in the Gülbahçe Bay during the Late Holocene period. Dondurur et al. (2011) and Sarı et al. (2016) investigated the Uzun Island and Gediz Delta by the seismic data. Their dataset reveal several biogenic gas accumulations and pockmarks near the active faults and around the pro-delta of Gediz River. Altan and Ocakoğlu (2016) imaged fluid outlets, mud volcanoes and gassy sediments. They also reported that pro-delta sediments of Gediz River is a possible fluid and/or gas area. Although mapped gas related structures mainly concentrate inside the Gulf, there is a gradual thickening of sediments offshore Balçova through the outer part of the Gulf. This could provide desirable high porosity and permeability conditions to host thermal water rising from deeper geological units (Serpen 2004).

In this study, we performed a set of numerical simulations to address following questions to widen our understanding of geothermal system extending offshore and its correlation with the land: (1) which structural conditions (presence of fault, thickness of sediments, seafloor bathymetry) are favourable for producing low-temperature hydrothermal circulations reported by previous studies within the study area?, (2) which driving mechanism(s) can explain the presence of those hydrothermal vents? and (3) is there any relationship with the on land geothermal system?

\section{Materials and methods}

\subsection{Seismic data}

Both single- and multi-channel seismic data were acquired to investigate the area by The General Directorate of Mineral Research and Exploration of Turkey (MTA). Single-channel data were collected in 2000 with $12.5 \mathrm{~m}$ receiver interval, $10 \mathrm{~m}$ group interval, $1 \mathrm{~ms}$ sampling interval, and $1.0 \mathrm{~s}$ record length (Ocakoğlu 2004; Altan and Ocakoğlu 2016). Multi-channel data were collected using 48 or 60 channels with $12.5 \mathrm{~m}$ receiver interval, $12.5 \mathrm{~m}$ group interval and $2 \mathrm{~ms}$ sampling interval (Ocakoğlu et al. 2005). Single-channel seismic sections were processed by Echos software with a conventional data processing sequence. It includes following steps: transcription, editing, selection of least noisy channel, in-line geometry definition, datum correction, sorting, NMO correction with a constant water velocity of $1500 \mathrm{~m} / \mathrm{s}$ for the seabed horizon, notch filtering for 15, 16 and $33 \mathrm{~Hz}$ frequencies, spherical divergence correction, finite-difference time migration, a trapezoidal band pass of minimum phase hamming filter with the corner frequencies 5-15-50-190 Hz (Altan and Ocakoğlu 2016).

A conventional data processing stream was applied to the multi-channel seismic data as follows: data transcription, in-line geometry definition, source-receiver array datum correction, editing, muting of direct and refracted waves, gain analysis, common depth point sorting, stacking 
velocity analysis, normal move-out correction and muting, stacking, spiking and predictive deconvolution, band pass filtering, finite-difference time migration and automatic gain control. Strong multiple reflections were suppressed when it was possible by predictive deconvolution techniques (Ocakoğlu et al. 2005).

We used 2D single-channel/multi-channel seismic lines (figure 1) to obtain the geometry of general structural units including locations of fault zones and thickness of sediments as well as the sea floor bathymetry. Depth sections were calculated from average RMS velocities obtained from the velocity analyses for multi-channel seismic lines to construct numerical models. For single-channel seismic sections, constant velocities are used. From these depth sections, we determined the thickness of the sediments and the depth of the basement to use them as constraints in the numerical simulations.

Imaged faults are almost vertical in the seismic sections and, are represented with higher permeability zones relative to their surrounding geological units. Thicknesses of faults are kept constant at 50 and $100 \mathrm{~m}$ for DOG-1 and Line-4, respectively. Numerical model box includes Plio-Quaternary sedimentary unit and Miocene basement, which are obtained from seismic sections (Ocakoğlu 2004; Altan and Ocakoğlu 2016). These two main units, separated by an erosion surface, are characterized by their internal reflection coefficient and continuity of high-amplitude reflections (Ocakoğlu et al. 2004). Yılmaz et al. (2000) suggested that this erosional surface marks the boundary between upper Miocene and Plio-Quaternary units. Furthermore, those units were also well correlated with the unconformity identified by the Turkish Petroleum Corporation (TPAO) borehole Foça1 (figure 1).

Seafloor bathymetry is not flat in seismic sections for both seismic profiles, thus producing different pressure gradients due to varying depth of water column. These pressure gradients were taken into account in the numerical simulations.

\subsection{Numerical model}

In this paper, we used a coupled transient numerical solution of fluid flow and heat transport to simulate the fluid circulation pattern and temperature along the selected 2D seismic profiles. Finite volume based Computational Fluid Dynamics (CFD) software, ANSYS FLUENT, was implemented to obtain the numerical solution of steady-state Navier-Stokes equation (e.g., Patankar 1980; Holmes and Connel 1989). Darcy's law (equation 1) is assumed to hold

$$
u=-\frac{K}{\mu}\left(\nabla P-\rho_{w} g\right),
$$

where $K$ is the permeability of the medium, $P$ is the pressure, $\rho_{w}$ is the fluid density, $g$ is the gravitational acceleration and $\nabla$ is the Laplacian operator. The fluid flow is considered laminar and viscous, and inertial effects are neglected. Fluid density $\left(\rho_{w}\right)$ is assumed to vary with temperature according to the Boussinesq approximation (equation 2)

$$
\rho_{w}=\rho_{0}\left[1-\beta\left(T-T_{0}\right)\right],
$$

where $\rho_{0}$ is the density at a temperature of $T=T_{0}$ and $\beta$ is the thermal expansion coefficient.

Darcy velocities should satisfy the equation of continuity, written as (equation 3)

$$
\nabla \cdot\left(\rho_{w} u\right)=0 .
$$

The energy conservation equation is written as follows (equation 4)

$$
\rho c_{p} \frac{\partial T}{\partial t}+\nabla \cdot\left(u \rho_{w} c_{p} T\right)=\nabla \cdot(\lambda \nabla T),
$$

where $c_{p}$ is the specific heat of the porous medium and $\lambda$ is the thermal conductivity of the saturated porous medium (McKibbin 1986; Nield and Bejan 1999). Local thermal equilibrium is considered, that is, the temperature will remain the same in the solid as in the corresponding pores.

The thermal and physical rock properties such as permeability, porosity, heat capacity and thermal conductivity, are held constant and uniform for the different rock units (sediments, faults, basement, etc.). They are summarized in tables 1 and 2 . Values of these properties are taken from the previous numerical modeling studies (Göktürkler et al. 2003; Gök et al. 2005; Magri et al. 2012), and geological investigations (Tezcan 1966; Yilmazer 1989; Karakullukcu 1991; Öngür 2001; Sari and Salk 2003; Serpen 2004).

In this study, dip angles of faults are about 85 degrees, thus, they are taken as vertical high permeable layers throughout all models. Faults are isotropic and modeled as equivalent porous media (EPM). In other words, they are implemented as high permeable areas of finite extension. The 
EPM approach is a well-established technique for representing faults and fractured zones (Weatherill et al. 2008; Graf and Therrien 2009), which requires less computational effort than discrete-fracture models. Depending on thermal and hydraulic conditions, faults can behave like a barrier or a conduit to transfer the fluid (Heffner and Fairley 2006). It is well known that faults can have two orders of magnitude permeability (e.g., Bense and Person 2006; Fairley and Hinds 2004; Magri et al. 2012). For simulations, constant fault zone permeability value is taken as $10^{-15} \mathrm{~m}^{2}$ as shown in table 2 . This value remains within the permeability range

Table 1. Fluid and heat flow parameters for DOG-1/Line-4.

\begin{tabular}{lll}
\hline Parameter & Value & Unit \\
\hline Density of fluid & 1000 & $\mathrm{~kg} / \mathrm{m}^{3}$ \\
Dynamic viscosity of fluid & $5 \mathrm{E}-5$ & $\mathrm{~kg} / \mathrm{m} \mathrm{s}$ \\
Specific heat capacity & 4200 & $\mathrm{~J} / \mathrm{kg} \mathrm{K}$ \\
Thermal expansion coeff. & $2.07 \mathrm{E}-4$ & $1 / \mathrm{K}$ \\
Gravitational acceleration & 9.81 & $\mathrm{~m} / \mathrm{s}^{2}$ \\
\hline
\end{tabular}

of previous similar studies. Since porosity values vary from 1 to $20 \%$ in permeable fault zones, an average value of $10 \%$ was selected for both models in this study. Furthermore, a constant porosity through the entire fault enables faster numerical convergence (Kühn et al. 2006).

\subsection{Finite-volume mesh structure and boundary conditions}

Triangular discretization with variable length is used to produce the numerical models for the $2 \mathrm{D}$ seismic lines. Total 233,671 and 79,102 mesh elements are used to construct the models for profiles DOG-1 and Line-4, respectively (figure 2). In the vicinity of the faults and the sediments, the mesh size is selected 15 meters. Away from these regions mesh size is gradually increased up to $50 \mathrm{~m}$. In convergence test, it is found that using different mesh sizes had no substantial effects on the fluid flow and temperature pattern.

The vertical boundaries of numerical models are assumed impermeable and adiabatic, thus,

Table 2. Permeabilities of geological units.

\begin{tabular}{lccc}
\hline Geological unit & $\begin{array}{c}\text { Permeability } \\
\left(\mathrm{m}^{2}\right)\end{array}$ & $\begin{array}{c}\text { Porosity } \\
(1)\end{array}$ & $\begin{array}{c}\text { Thermal conductivity } \\
(\mathrm{W} / \mathrm{mK})\end{array}$ \\
\hline Plio-Quaternary sediment & $2 \mathrm{E}-16$ & 0.2 & 1.5 \\
Fault & $1 \mathrm{E}-15$ & 0.1 & 2.0 \\
Miocene basement & $1 \mathrm{E}-16$ & 0.03 & 3.5 \\
\hline
\end{tabular}

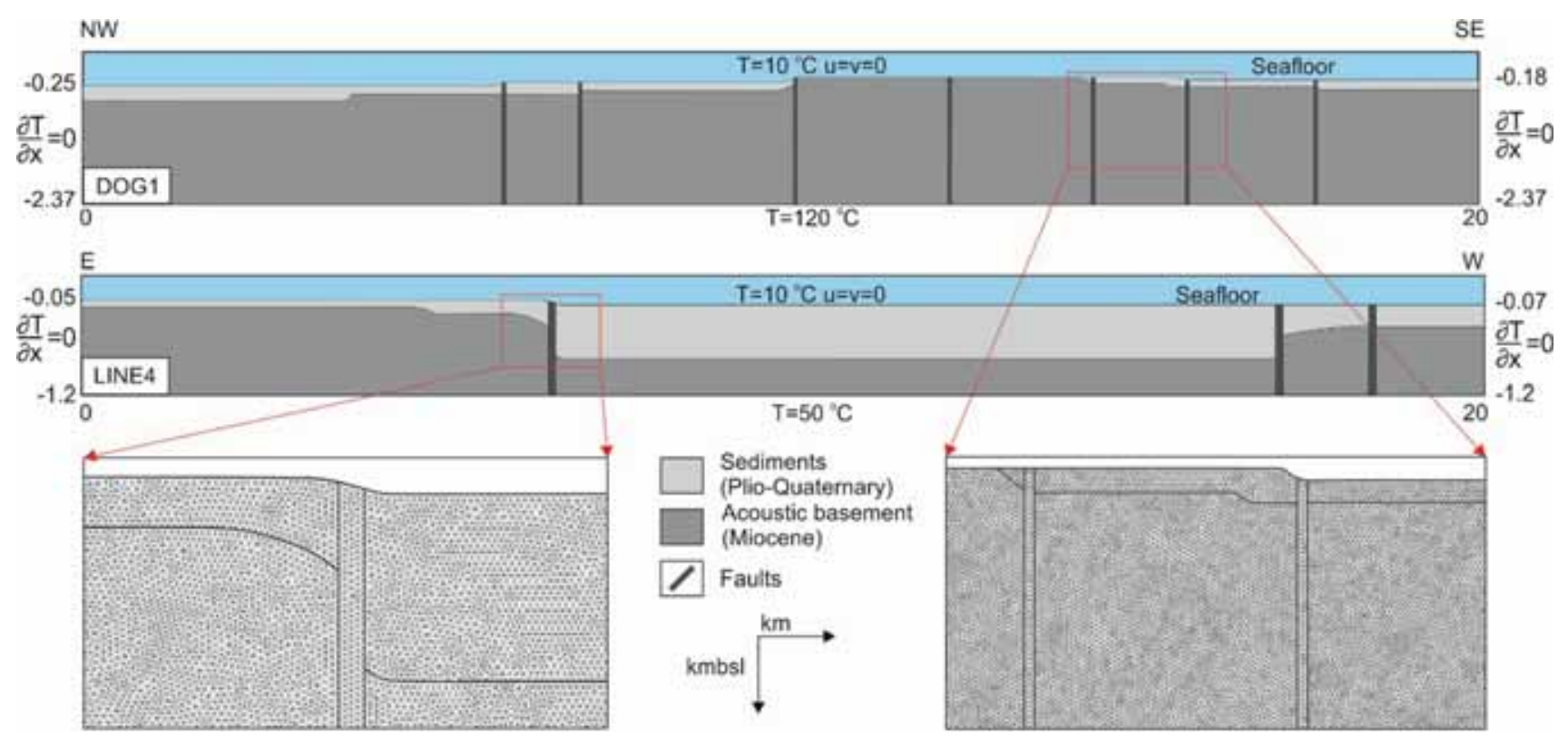

Figure 2. Model set-up for numerical calculations for DOG-1 (top), Line-4 (middle) and triangular mesh structure (bottom). Boundary conditions are also presented. 
mass and heat transfer are not allowed through these walls. Horizontal boundaries of the system are isothermal. Upper wall temperature is kept constant as $10^{\circ} \mathrm{C}$. At the bottom wall, fixed temperature boundary conditions are also applied and the constant bottom temperatures of 120 and $50^{\circ} \mathrm{C}$ are taken for DOG-1 and Line-4, respectively. These values are obtained from previous heat flow studies (Göktürkler et al. 2003; Magri et al. 2010). Models for both seismic sections consider seafloor bathymetry variations.

Models have open top systems, which allow water to flow in and out. The water column depth determines pressure boundary condition at the top of the model. Gradual pressure changes are applied in transition regions of different depths in seafloor. Numerical simulations indicate that the existence of faults can form the thermal convective flow pattern by constraining the size and location of convective cells (e.g., Lopez and Smith 1995; Yang et al. 1998; Simms and Garven 2004; Yang et al. 2004; Düşünür Doğan 2014). Even fractures with apertures in the order of a few millimeters can convey significant flow rates of hot water from the depths in the order of a few kilometers (Lowell 1975). Furthermore, faults can trigger convection in neighboring units even though the thermal conditions are not suitable for the convective flow. Previous works show that the strength of the convective flow is proportional to the Rayleigh number. The Rayleigh number of the system, which is an indicator of the mode of the heat transfer and the strength of the convection, is calculated as 4.6 for this study. This value is well below the critical value of 17.65 for open top systems (Simms and Garven 2004). Although the Rayleigh number of the system in this study is below the critical Rayleigh number, faults within the system lead to circulation cells.

\section{Results}

A set of numerical calculations are performed in order to understand the effect of faulting, sediment thickness and seafloor bathymetry on thermal regime and fluid flow pattern of the area. Numerical models presented here are intended to understand transport processes and their relationship with the active faults offshore. For this purpose: seismic section, temperature distribution and flow paths are correlated to each other.
Figure 3 shows the steady-state results for DOG-1 seismic section located offshore Doganbey, delimited by Tuzla Fault Zone. Study profile of $20 \mathrm{~km}$ extends from NW to SE crossing the Seferihisar Rise. Stratigraphy of the model, which includes Plio-Quaternary basin deposits and Miocene basement, has the depth of $2.3 \mathrm{~km}$. According to the seismic section, sediment thickness gradually increases away from the Seferihisar Rise (figure 3a).

It is found that the active faults and the Seferihisar Rise are the main structural units which control the temperature distribution and the fluid flow of the model. Boundary faults of the Seferihisar Rise act as a pathway to the down flow into the sediments and basement. Isotherms in the vicinity of faults and the Seferihisar Rise are bent parallel to the fault flanks, on the other hand, remaining part of the model shows smooth temperature curves as expected. In the rise, temperature gradient slightly increases due to the effects of bathymetry that drives the fluid flow. As an example, $100^{\circ} \mathrm{C}$ isotherm is located at a depth of $\sim 1.7 \mathrm{~km}$ at the flanks, whereas it is at $\sim 0.6 \mathrm{~km}$ depth at the center of the rise (figure $3 \mathrm{~b}$ ).

A thin sedimentary layer in DOG-1 seismic section prevents the formation of small-scale circulation cells within. Fluid flow circulates down to the basement along the sides of the Seferihisar Rise and move up to the top of the central high. Average fluid velocities $5 \times 10^{-10}, 3 \times 10^{-10}$ and $3 \times 10^{-12} \mathrm{~m} / \mathrm{s}$ are found within faults, sediments and basement, respectively (figure 3c). It is well known that permeability tends to decrease with increasing depth, therefore, we performed various simulations of different basement permeability ranges between $10^{-18}$ and $10^{-20} \mathrm{~m}^{2}$. No particular changes in circulation pattern but modest changes in velocity magnitudes are observed in these simulations. It shows that numerical models are not particularly sensitive to the host rock permeability values within the range of $10^{-18}$ and $10^{-20} \mathrm{~m}^{2}$.

A region on the SE tip of the Seferihisar Rise bounded by normal fault zone is magnified to visualize the small-scale circulation (figure $3 \mathrm{~d}$ ). Streamlines in figure 3(d) suggest that seawater penetrates into the sediments and the faults, and then moves in a clockwise rotation at the southeast side of the rise due to the hydrostatic pressure differences.

Line-4 seismic section also extends $20 \mathrm{~km}$ in E-W direction. Study profile highlights normal and strike slip faults on the east and strike-slip 

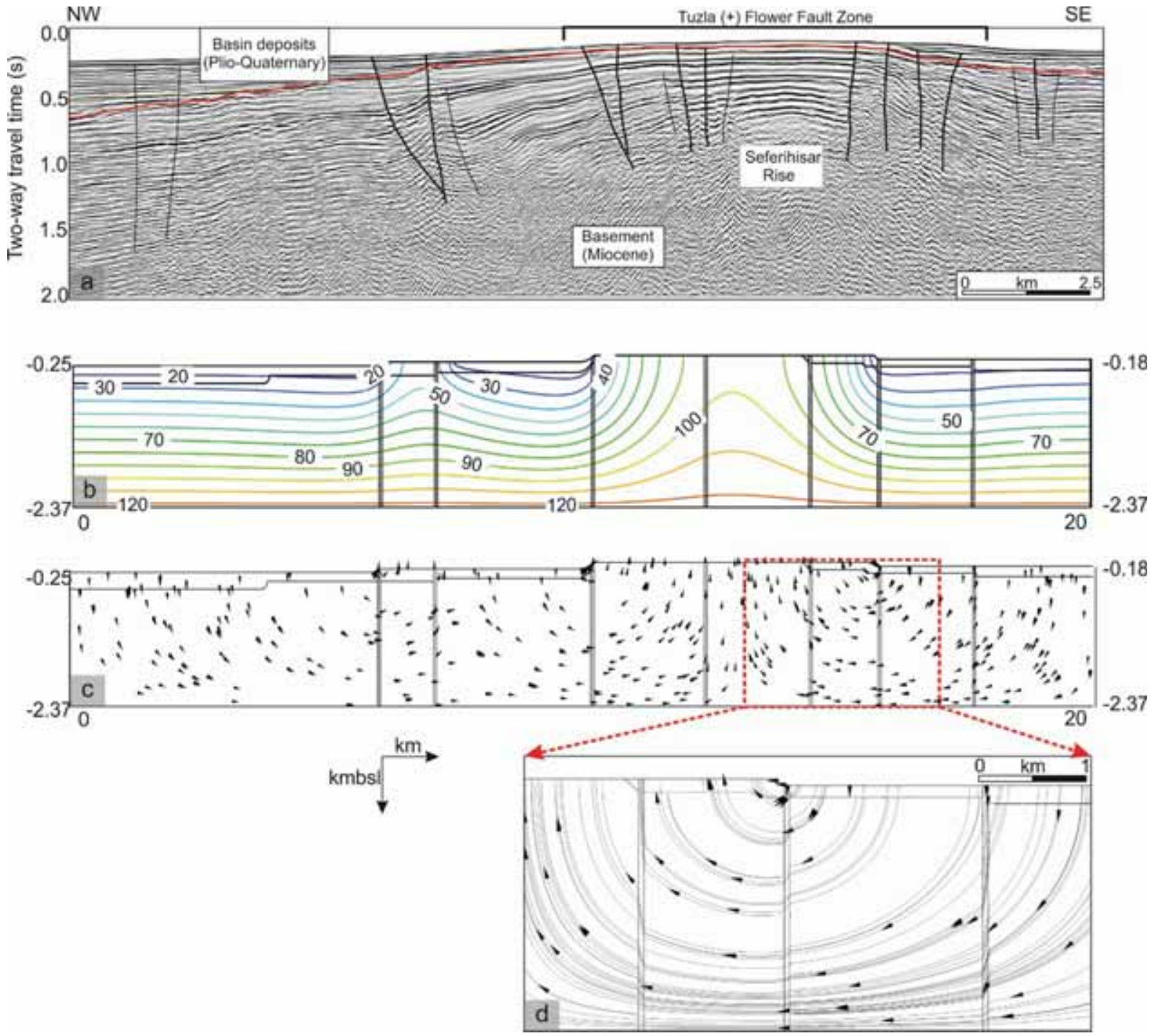

Figure 3. (a) DOG-1 seismic section (Altan and Ocakoğlu 2016), (b) calculated temperature pattern, (c) fluid flow vectors (in order to visualize the fluid flow vectors, all vector length kept constant, independent from their Darcy velocities), and (d) calculated streamlines for a selected area. Streamlines were sparsely plotted for a better view.

fault zone on the west (Ocakoğlu et al. 2005; Altan and Ocakoğlu 2016). Both fault zones cut the Miocene basement and Plio-Quaternary sediments and reach to the seafloor (figure 4a). Model extends up to $1.2 \mathrm{~km}$ depth, where faults can be marked on the seismic section. As shown in seismic section Line-4, sediment thickness drastically increases from $200 \mathrm{~m}$ in the east to $750 \mathrm{~m}$ in the center of the profile under the effect of faulting. The existence of the thick sediment and faults are the dominant structural units for this profile (Line-4), which shape the fluid flow and temperature distribution. Far from the normal fault, where the medium is not influenced by fluid circulation, isotherms are smooth and horizontal with the linear vertical temperature gradient. Nonlinear vertical temperature gradient with peak surface temperature values are seen in the vicinity of normal fault (figure 4b).

Presence of thick sediments on Line- 4 promotes the circulation cell penetrating down to the base of the model and moving up to the seafloor (figure 4c). Fluid velocity vectors are oriented in upward direction passing through the normal fault, on the contrary, they point in downward direction inside the strike slip fault zones. Average fluid velocities are $1 \times 10^{-11}, 2 \times 10^{-10}$ and $5 \times 10^{-11} \mathrm{~m} / \mathrm{s}$ within faults, sediments and basement, respectively. Fluid circulations are not only found in the fault zones but also in the permeable thick sediment layer (figure 4c). The location of fluid exits are significantly influenced by fluid flow channeling inside 

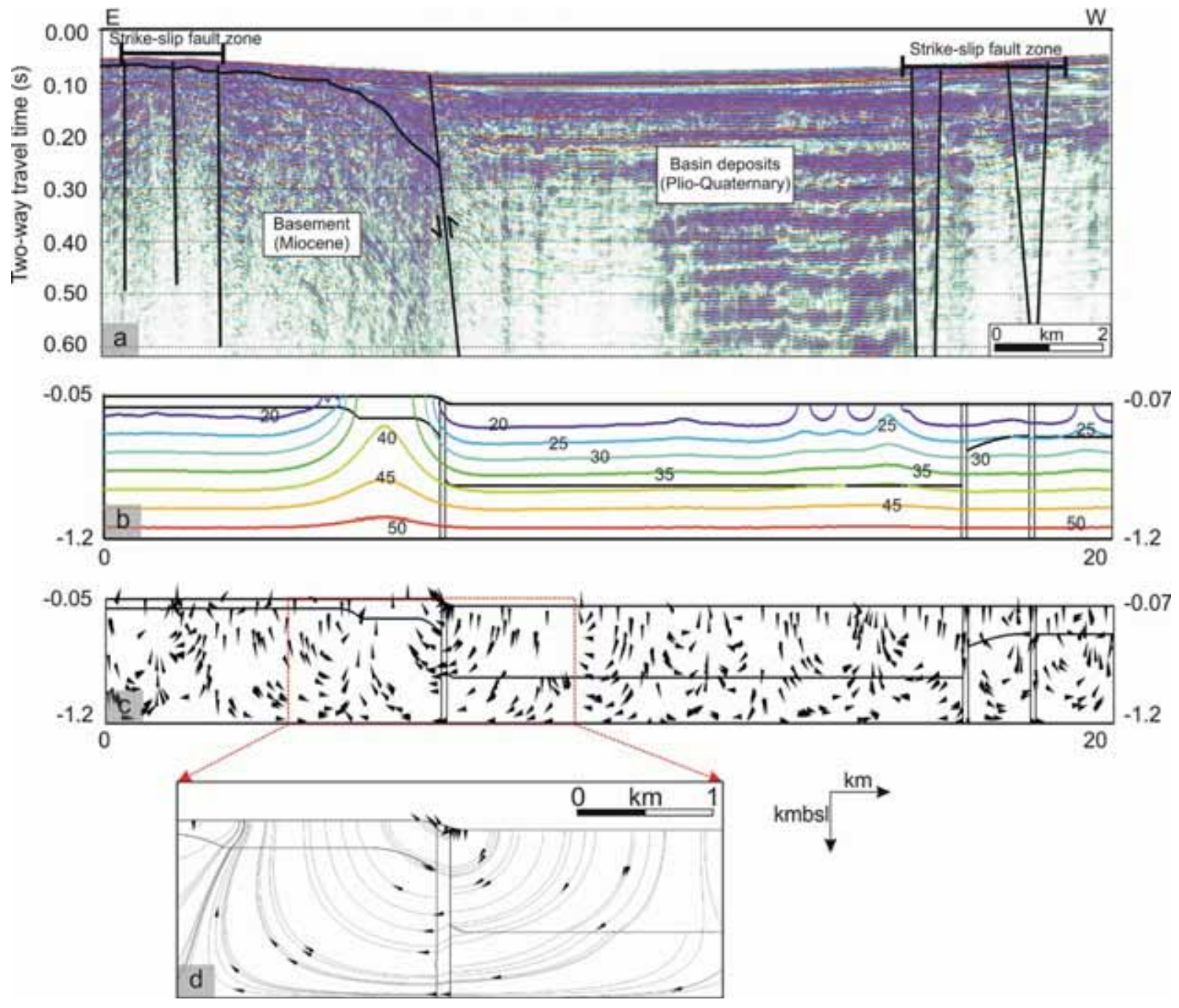

Figure 4. (a) Line-4 seismic section (Altan and Ocakoğlu 2016), (b) calculated temperature pattern, (c) fluid flow vectors (in order to visualize the fluid flow vectors, all vector length kept constant, independent from their Darcy velocities), (d) calculated streamlines for a selected area. Streamlines were sparsely plotted for a better view.

the fault and the sediments. Even though there are diffuse flow, vents predicted by numerical model throughout the Line-4, main fluid exit is located about the normal fault. Maximum temperature for outlet vents are found between 21 and $36^{\circ} \mathrm{C}$ (figure 4b).

We pay close attention to the normal fault where main fluid discharges are located (figure 4d). In DOG-1 model, normal faults are the dominant effect on the fluid flow pattern, however, in Line4 model, the thick sedimentary layer and the bathymetric differences are the dominant effects. Calculated streamlines indicate that seawater seeps into thick sedimentary unit resulted in clockwise rotation of fluid flow vectors, similar to the DOG-1 model.

Figure 5(a) shows reflection strength section (modified from Altan and Ocakoğlu 2016) with upwelling fluid flow zones (indicated by red arrows) in Line-4 and corresponding predicted model streamlines (figure 5b). Altan and Ocakoğlu (2016) marked possible existence of fluid and/or gas saturated zones as well as discharge zones in the Line-4 offshore Gediz River. Similarly, previous seismic attribute study of Gülbahçe Bay reveals the existence of fluid and/or gas saturated zones as well as discharge zones inside the gulf (Pekçetinöz 2010). Dondurur et al. (2011) and Sarı et al. (2016) mapped gas related features such as gas chimneys and pockmarks near the Uzun Island. They also reported that the rapid burial and oxidization of organic material rich sediments transported by the Gediz River might produce this gassy environment. It is shown that numerical models in this study predict the zones of observed fluid flow and outlet vents well. 

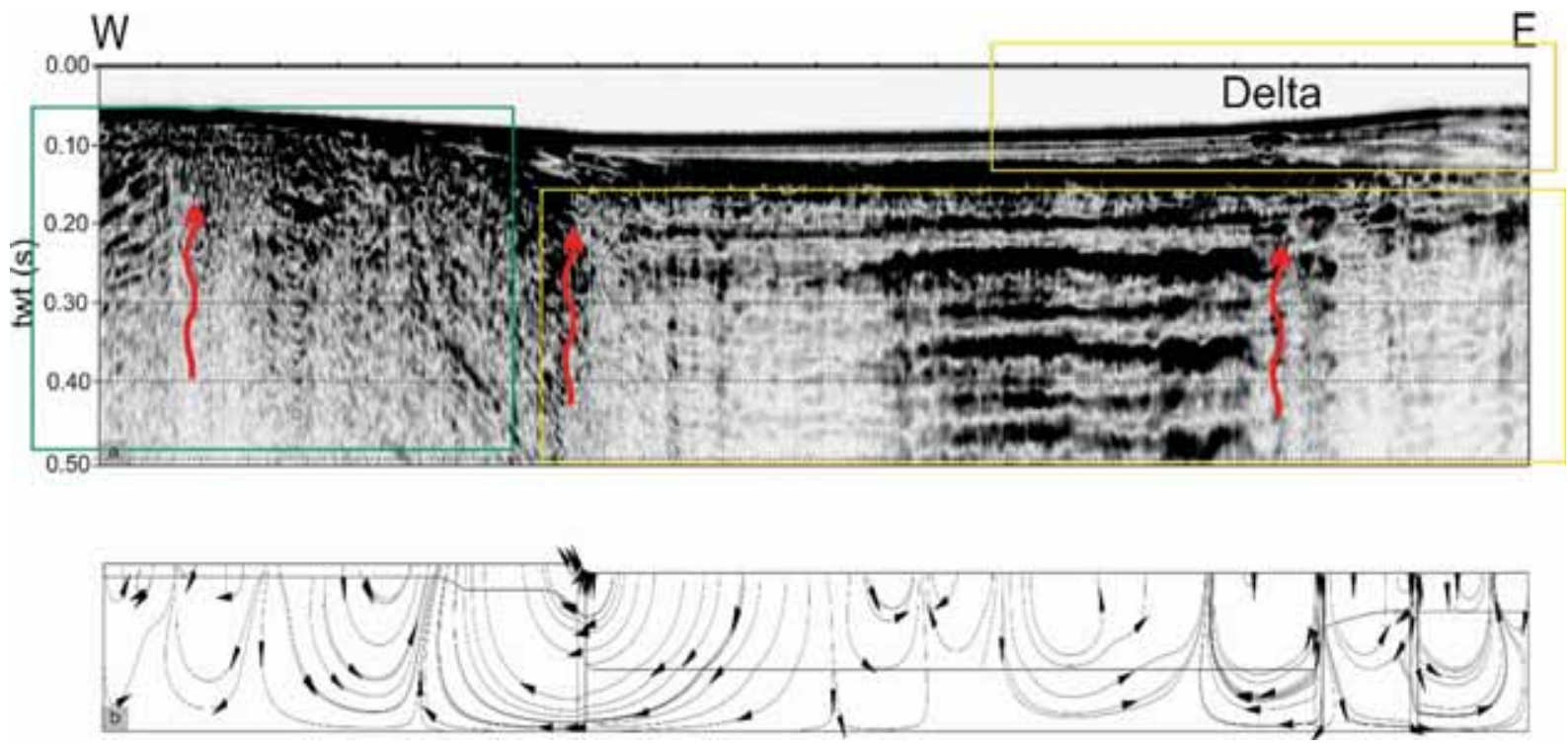

Figure 5. (a) Reflection strength for Line-4 (modified from Altan and Ocakoğlu 2016), (b) calculated streamlines. Red arrows indicate expected fluid flow exits via faults and rectangles indicate weak reflection zones on sediments (yellow) and basement (green) units correspond to small scale fluid circulations. Streamlines were sparsely plotted for a better view.

\section{Conclusions}

Shallow-water hydrothermal systems are excellent candidate to understand the interaction between the processes of deep-water and on land hydrothermal systems. Our approach is based on the simplified models, which are used to figure out hydrothermal regime in one of the shallow-water hydrothermal systems in offshore Izmir. Although simple, such models can be considered as preliminary estimates of fluid flow and temperature patterns in the region. This study is the first one to gain insight of the transport mechanisms of the shallow underwater system of offshore Izmir. Following conclusions are deduced from coupled fluid flow and heat transfer simulations.

- Several parameters such as sediment thickness, presence of faults and seafloor bathymetry, interact but their contributions are not equal on fluid flow and temperature patterns. Tuzla Fault Zone plays a major role in controlling fluid flow distribution, shapes the temperature gradient and influences the locations of outflow vents, which are similar to the previous on land studies. However, fluid flow is not vigorous enough to disturb temperature field away from the Tuzla Fault Zone.

- Pressure gradients due to the bathymetrical differences at both of the seismic sections play a critical and distinctive role in shaping fluid flow pattern. Therefore, this appears a critical issue for numerical calculations offshore. A special treatment is required for inclined seafloor to define hydrostatic pressure gradient. Otherwise, models demonstrate pseudo-fluid movements at the transition region between flat and inclined surfaces.

- Dominance between hydrostatic and buoyant forces is determined by the permeability of the medium. In numerical models, fluid flow is channelized into the seafloor near to fault zones due to the permeability differences, which produce outlet vents. Small-scale circulations inside the thick sediment column is also triggered by the presence of faults. Those small circulations are in good agreement with the weak reflection zones marked in seismic sections. Localization of the hot fluids via faults can help to produce suitable environment for the shallow-sea habitats.

\section{Acknowledgements}

This study was supported by the Istanbul Technical University (ITU) Research Fund, Project No. 37167. The authors thank Duygu Yağci for her contribution at preliminary models. The authors express their gratitude to the Associate Editor, Subimal Ghosh and the anonymous reviewer for their valuable suggestions. 


\section{References}

Aksoy N, Serpen U and Filiz S 2008 Management of the Balçova-Narlidere geothermal reservoir, Turkey; Geothermics 37 444-466.

Altan Z and Ocakoğlu N 2016 Shallow seismic study of the geothermal areas in the Gülbahçe Bay and İzmir Gulf (Aegean Sea, western Turkey); Mar. Geophys. Res. 37 297-311.

Bense V F and Person M A 2006 Faults as conduit-barrier systems to fluid flow in siliciclastic sedimentary aquifers; Water Resour. Res. 42(5), https://doi.org/10.1029/ 2005WR004480.

Bozkurt E, Park R G and Winchester J A 1993 Evidence against the core/cover interpretation of the southern sector of the Menderes Massif, west Turkey; Terra Nova $\mathbf{5}$ 445-451.

Bozkurt E 2001 Neotectonics of Turkey - a synthesis; Geodin. Acta 14 3-30.

Bozkurt E and Oberhänsli R 2001 Menderes massif (western Turkey): Structural, metamorphic and magmatic evolution - a synthesis; Int. J. Earth Sci. 89 679-708.

Candan O, Koralay O E, Akal C, Kaya O, Oberhänsli R, Dora O Ö, Konak N and Chen F 2011 Supra-PanAfrican unconformity between core and cover series of the Menderes massif/Turkey and its geological implications; Precamb. Res. 184 1-23.

Catlos E J and Çemen İ 2005 Monazite ages and the evolution of the Menderes massif, western Turkey; Int. J. Earth Sci. 94 204-217.

Collins A S and Robertson A H F 1997 Lycian mélange, southwestern Turkey: An emplaced Late Cretaceous accretionary complex; Geology 25 255-258.

Dondurur D, Çifci G, Drahor M and Coşkun S 2011 Acoustic evidence of shallow gas accumulations and active pockmarks in the İzmir Gulf, Aegean Sea; Mar. Pet. Geol. 28 1505-1516.

Drahor M G and Berge M A 2006 Geophysical investigations of the Seferihisar geothermal area, western Anatolia, Turkey; Geothermics 35 302-320.

Düşünür Doğan D 2014 Investigation of fault-related small-scale fluid flow in geothermal fields by numerical modeling; Turkish J. Earth Sci. 23 67-79.

Erdogmus B, Toksoy M, Ozerdem B and Aksoy N 2006 Economic assessment of geothermal district heating systems: a case study of Balcova-Narlidere, Turkey; Energ. Buildings 38 1053-1059.

Ersoy Y E, Helvaci C and Palmer M R 2012 Petrogenesis of the Neogene volcanic units in the NESW-trending basins in western Anatolia, Turkey; Contrib. Mineral. Petrol. 163 379-401.

Fairley J P and Hinds J J 2004 Field observation of fluid circulation patterns in a normal fault system; Geophys. Res. Lett. 31(19), https://doi.org/10.1029/2004GL020812.

Filiz Ş and Tarcan G 1993 Hydrogeology of geothermal area in the south of Seferihisar (Izmir); TPJD Bült. 5(1) 97-112.

Fontaine F J and Wilcock W S D 2007 Two-dimensional numerical models of open-top hydrothermal convection at high Rayleigh and Nusselt number: Implications for mid-ocean ridge hydrothermal circulation; Geochem. Geophys. Geosys. 8(7) 1-17.
Genç C, Altunkaynak S, Karacık Z, Yazman M and Yilmaz Y 2001 The Çubukludağ graben, south of Izmir: Tectonic significance in the Neogene geological evolution of the Western Anatolia; Geodin. Acta 14 1-12.

German C R, Parson L M and Team H S 1996 Hydrothermal exploration near the Azores triple junction: Tectonic control of venting at slow-spreading ridges; Earth Planet. Sci. Lett. 138 93-104.

Gessner K, Gallardo L A, Markwitz V, Ring U and Thomson S N 2013 What caused the denudation of the Menderes massif: Review of crustal evolution, lithosphere structure, and dynamic topography in southwest Turkey; Gondwana Res. 24 243-274.

Gök I M, Sarak H, Onur M, Serpen U and Satman A 2005 Numerical modeling of the Balcova-Narlidere geothermal field, Turkey; Proceedings of the World Geothermal Congress, Antalya, Turkey.

Göktürkler G, Salk M and Sari C 2003 Numerical modeling of the conductive heat transfer in western Anatolia; J. Balkan Geophys. Soc. 6 1-15.

Graf T and Therrien R 2009 Stable-unstable flow of geothermal fluids in fractured rock; Geofluids 9 138-152.

Güngör T and Erdoğan B 2001 Tectonic significance of mafic volcanic rocks in a Mesozoic sequence of the Menderes massif, west Turkey; Int. J. Earth Sci. 91 386-397.

Heffner J and Fairley J 2006 Using surface characteristics to infer the permeability structure of an active fault zone; Sedim. Geol. 184 255-265.

Holmes D and Connel S 1989 Solution of the 2D Navier-Stokes equations on unstructured adaptive grids; 9th Computational Fluid Dynamics Conference, American Institute of Aeronautics and Astronautics.

Humphris S E, Fornari D J, Scheirer D S, German C R and Parson L M 2002 Geotectonic setting of hydrothermal activity on the summit of Lucky Strike seamount $\left(37^{\circ} 17^{\prime} \mathrm{N}\right.$, Mid-Atlantic Ridge). Geochem. Geophys. Geosys. 3(8), https://doi.org/10.1029/2001GC000284.

Ilkışık M 1995 Regional heat flow in western Anatolia using silica temperature estimates from thermal springs; Tectonophys. 244 175-184.

Karakullukcu K 1991 Izmir-Menderes-Görece Köyü Camur Dere Göleti Mühendislik jeolojisi; Master thesis, Dokuz Eylül Üniversitesi, Izmir.

Koralay O E, Candan O, Chen F, Akal C, Oberhansli R, Satir M and Dora O Ö 2012 Pan-Africn magmatism in the Menderes massif: Geochronological data from leucocratic tourmaline orthogneisses in western Turkey; Int. J. Earth Sci. 101 2055-2081.

Kühn M, Dobert F and Gessner K 2006 Numerical investigation of the effect of heterogeneous permeability distributions on free convection in the hydrothermal system at Mount Isa, Australia; Earth Planet. Sci. Lett. 244 655671.

Le Pichon X and Angelier J 1981 The Aegean Sea; Phil. Trans. Roy. Soc. 300 357-372.

Lopez D L and Smith L 1995 Fluid flow in fault zones: Analysis of the interplay of convective circulation and topographically driven groundwater flow; Water Resour. Res. 31 1489-1503.

Lowell R P 1975 Circulation in fractures, hot springs, and convective heat transport on mid-ocean crests; Geophys. J. Roy. Astron. Soc. 39 351-365. 
Magri F, Akar T, Gemici U and Pekdeğer A 2010 Deep geothermal groundwater flow in the Seferihisar-Balcova area, Turkey: Results from transient numerical simulations of coupled fluid flow and heat transport processes; Geofluids 10 388-405.

Magri F, Akar T, Gemici U and Pekdeğer A 2012 Numerical investigations of fault-induced seawater circulation in the Seferihisar-Balçova geothermal system, western Turkey; Hydrogeol. J. 20 103-118.

McKenzie D 1972 Active tectonics of the Mediterranean region; Geophys. J. Roy. Astron. Soc. 30 109-185.

McKibbin R 1986 Heat transfer in a vertically-layered porous medium heated from below; Transp. Porous Med. 1(4) 361-370.

Mutlu H and Güleç N 1998 Hydrogeochemical outline of thermal waters and geothermometry applications in Anatolia (Turkey); J. Volcanol. Geotherm. Res. 85 495-515.

Nield D A and Bejan A 1999 Convection in porous media; Springer, New York.

Ocakoğlu N 2004 Investigation of the active tectonism of the Gulf of Izmir and offshore Alaçati-Doğanbey-Kuşadasi by seismic reflection data; $\mathrm{PhD}$ Thesis, Institute of Science and Technology, Istanbul Technical University, Istanbul, Turkey.

Ocakoğlu N, Demirbağ E and Kuşçu İ 2004 Neotectonic structures in the area offshore Alaçati, Doğanbey and Kuşadası (western Turkey): Evidence of strike-slip faulting in the Aegean extensional province; Tectonophys. 391 67-83.

Ocakoğlu N, Demirbağ E and Kuşçu İ 2005 Neotectonic structures in İzmir Gulf and surrounding regions (western Turkey): Evidences of strike-slip faulting with compression in the Aegean extensional regime; Mar. Geol. 219 155-171.

Okay A I 2001 Stratigraphic and metamorphic inversions in the central Menderes massif: A new structural model; Int. J. Earth Sci. 59 709-727.

Okay A I, Kaşlılar-Özcan A, İmren C, Boztepe-Güney A, Demirbağ E and Kuşçu I 2001 Active faults and evolving strike-slip basins in the Marmara Sea, northwest Turkey: A multichannel seismic reflection study; Tectonophys. $\mathbf{3 2 1}$ $189-218$

Ozel E 2000 Usage of Curie depths for the determination of geothermal areas in the Izmir Bay; 10th International Offshore and Polar Engineering Conference, Seattle, Washington, USA.

Öngür T 2001 Geology of Izmir Agamemnon hot springs Balçova geothermal area and new conceptual geological model; Report for Balçova Geothermal Ltd. Izmir Turkey (in Turkish).

Özürlan G, Candansayar M E and Şahin M H 2006 Deep resistivity structure of the Dikili-Bergama region, west Anatolia, revealed by two-dimensional inversion of vertical electrical sounding data; Geophys. Prospect. 54 187197.

Patankar S 1980 Numerical heat transfer and fluid flow; CRC Press, New York.

Pekçetinöz B 2010 The investigation of geothermal potential of Gulf of Izmir and surrounding area (Gülbahçe Bay); PhD Thesis, Dokuz Eylül University, Izmir.

Pfister M, Ladislaus R and Şakir S 1988 Geothermal reconnaissance of the Marmara Sea region (NW Turkey):
Surface heat flow density in an area of active continental extension; Tectonophys. 291 77-89.

Pichler T, Veizer J and Hall G E M 1999 The chemical composition of shallow-water hydrothermal fluids in Tutum Bay, Ambitle Island, Papua New Guinea and their effect on ambient seawater; Mar. Chem. 64(3) 229 252.

Pichler T 2005 Stable and radiogenic isotopes as tracers for the origin, mixing and subsurface history of fluids in submarine shallow-water hydrothermal systems; J. Volcanol. Geotherm. Res. 139 211-226.

Ristova P P, Pichler T, Friedrich M W and Buhring S I 2017 Bacterial diversity and biochemistry of two marine shallow-water hydrothermal systems off Dominica (Lesser Antilles); Front. Microbiol. 8 1-17.

Sari C and Salk M 2003 Heat flow investigations in Western Anatolia; Geophys. Res. Abstracts, 5, 08509, EGS-AGUEUG Joint Assembly, Nice, France.

Sarı C, Dondurur D, Cifci G, Aydemir A and Drahor M G 2016 Natural and anthropogenic submarine morphologies revealed by high resolution acoustic data in the Gulf of Izmir, western Turkey; Mar. Pet. Geol. 71 211-224.

Sedwick P and Stüben D 1996 Chemistry of shallow submarine warm springs in an arc-volcanic setting: vulcano Island, Aeolian Archipelago, Italy; Mar. Chem. 53 146161.

Serpen Ü 2004 Hydrogeological investigations on Balçova geothermal system in Turkey; Geothermics 33 309-335.

Seyitoğlu G, Işık V and Çemen I 2004 Complete Tertiary exhumation history of the Menderes massif, western Turkey: An alternative working hypothesis; Terra Nova 16 358-364.

Seyitoğlu G and Işik V 2009 Meaning of the Küçük Menderes graben in the tectonic framework of the central Menderes metamorphic core complex (western Turkey); Geol. Acta 7 323-331.

Simms M A and Garven G 2004 Thermal convection in faulted extensional sedimentary basins: Theoretical results from finite element modeling; Geofluids 4 109-130.

Singh S C, Crawford W C, Cartoon H, Seher T, Combier V, Cannat M, Canales J P, Dusunur D, Escartin J and Miranda M 2006 Discovery of a magma chamber and faults beneath a Mid-Atlantic Ridge hydrothermal field; Nature 442 1029-1032.

Weatherill D, Graf T, Simmons C T, Cook P G, Therrien R and Reynolds D A 2008 Discretizing the fracture-matrix interface to simulate solute transport; Ground Water $\mathbf{4 6}$ 606-615.

Tarcan G and Gemici Ü 2003 Water geochemistry of the Seferihisar geothermal area, İzmir, Turkey; J. Volcanol. Geotherm. Res. 126 225-242.

Tezcan K 1966 Izmir Agamemnon Jeofizik Etüdlerinin Jeotermik Enerji Bakımından Değerlendirilmesi; In: MTA Ege Bölge Kütüphanesi Report 98/3072 _Izmir.

Yagc1 D 2015 Temperature and Flow Modelling in Izmir, Gülbahçe And Siğacik Bay, MSc Thesis, Istanbul Technical University Institute of Science and Technology.

Yang J, Latychev K and Edwards R N 1998 Numerical computation of hydrothermal fluid circulation in fractured earth structures; Geophys. J. Int. 135 627-649.

Yang J, Large R R and Bull S W 2004 Factors controlling free thermal convection in faults in sedimentary basins: 
Implications for the formation of zinc-lead mineral deposits; Geofluids 4 237-247.

Yılmaz Y, Genc S C, Guürer F, Bozcu M, Yilmaz K, Karacık Z, Altunkaynak S and Elmas A 2000 When did the western Anatolian grabens begin to develop?; In: Tectonics and magmatism in Turkey andsurrounding area (eds) Bozkurt
E, Winchester J A and Piper J D A, Geol. Soc. London, Spec. Publ. 173 353-384.

Yilmazer S 1989 Geochemical features of Balçova hot springs and geothermal energy possibilities for the area; $\mathrm{PhD}$ thesis, Akdeniz University, Graduate School, Isparta, Turkey.

Corresponding editor: Subimal Ghosh 